\title{
EVALUATION OF PRIMARY PROPHYLAXIS WITH PROPRANOLOL AND ELASTIC BAND LIGATION IN VARICEAL BLEEDING IN CIRRHOTIC CHILDREN AND ADOLESCENTS
}

\author{
Júlio Rocha PIMENTA ${ }^{1}$, Alexandre Rodrigues FERREIRA ${ }^{1,2}$, \\ Paulo Fernando Souto BITTENCOURT ${ }^{1}$, Camilo Brandão de RESENDE ${ }^{2}$, \\ Eleonora Druve Tavares FAGUNDES ${ }^{1,2}$ and Isabela Maria Lopes da SILVA ${ }^{2}$
}

Received 13/3/2016 Accepted 25/5/2016

\begin{abstract}
Background - The efficacy of nonselective $\beta$-blocker and endoscopic procedures, such as endoscopic variceal ligation, as primary prophylaxis of variceal hemorrhage in cirrhotic adults was demonstrated by numerous controlled trials, but in pediatric population, few are the number of studies. Objective - The objective of this study is to evaluate the primary prophylaxis with $\beta$-blocker in cirrhotic children and adolescents with portal hypertension. Methods - This is a cohort study encompassing 26 cirrhotic patients. $\beta$-blocker prophylaxis was performed with propranolol. When contraindicated the use of $\beta$-blocker, or if side effects presents, the patients were referred to endoscopic therapy with band ligation. Patients were evaluated by endoscopy, and those who had varicose veins of medium and large caliber or reddish spots, regardless of the caliber of varices, received primary prophylaxis. Results - Of the 26 patients evaluated, $9(34.6 \%)$ had contraindications to the use of propranolol and were referred for endoscopic prophylaxis. Six (35.3\%) of the 17 patients who received $\beta$-blocker (propranolol), had bled after a median follow-up time of 1.9 years. $\beta$-blockage dosage varied from $1 \mathrm{mg} / \mathrm{kg} /$ day to $3.1 \mathrm{mg} / \mathrm{kg} /$ day and seven $(41.2 \%)$ patients had the propranolol suspended due to fail of the $\beta$-blockage or adverse effects, such as drowsiness, bronchospasm and hypotension. Patients who received endoscopic prophylaxis (elastic bandage) had no bleeding during the follow-up period. Conclusion - All of the patients that had upper gastroinstestinal bleeding in this study were under propranolol prophylaxis. The use of propranolol showed a high number of contraindications and side effects, requiring referral to endoscopic prophylaxis. The endoscopic prophylaxis was effective in reducing episodes of bleeding.

HEADINGS - Liver cirrhosis. Esophageal and gastric varices, therapy. Disease prevention. Propranolol. Gastrointestinal endoscopy, rehabilitation. Child. Adolescent.
\end{abstract}

\section{INTRODUCTION}

Portal hypertension is a common complication of chronic liver disease in children ${ }^{(3)}$. In cirrhosis, portal pressure initially elevates as a consequence of an increased resistance to flow mostly due to an architectural distortion of the liver secondary to fibrous tissue and regenerative nodules ${ }^{(6,11,16)}$. In addition, intrahepatic increased vascular tone, small vessel portal thrombosis, and splanchnic arteriolar dilatation exacerbate portal hypertension ${ }^{(3,6,11)}$.

Varices are portosystemic collaterals formed as a result of elevated hepatic venous pressure gradient, which dilates preexisting vascular channels ${ }^{(11,16)}$.
Variceal bleeding occurs when variceal wall tension is increased beyond the maximum tolerable threshold, as a result of increased variceal vein diameter, decreased wall thickness, and increased intraluminal pressure $^{(11)}$. In some pediatric hepatology referral centers, more than $50 \%$ of cirrhotic children have varices $^{(9,11,16)}$

Endoscopy is the reference standard for diagnosis of esophageal varices. Adults who are likely to have portal hypertension and to be at risk of esophageal varices should be screened by endoscopy, and who have varicose veins of medium and large caliber or reddish spots, regardless of the caliber of varices have been recommended primary prophylaxis ${ }^{(18)}$.

Setor de Gastroenterologia Pediátrica, Hospital das Clínicas, Universidade Federal de Minas Gerais, Belo Horizonte, MG, Brasil; ${ }^{2}$ Departamento de Pediatria, Faculdade de Medicina, Universidade Federal de Minas Gerais, Belo Horizonte, MG, Brasil.

Correspondence: Júlio Rocha Pimenta. Rua Samuel Pereira, 178, 02. Anchieta - CEP: 30310-550 - Belo Horizonte, MG, Brasil. Email: juliopimenta@yahoo.com 
Primary prophylaxis is intended to prevent the first episode of variceal bleeding in an individual who has varices ${ }^{(9)}$. There is no consensus on whether primary prophylaxis is indicated for cirrhotic children ${ }^{(3,6,11)}$. The efficacy of nonselective $\beta$-blocker and endoscopic procedures, such as endoscopic variceal ligation (EVL), as primary prophylaxis of variceal hemorrhage in cirrhotic adults was demonstrated by numerous controlled trials ${ }^{(6,7,14)}$. Primary prophylaxis is also commonly used in cirrhotic children, despite the lack of pediatric data, based on extrapolations of the adult studies to children ${ }^{(3,11)}$.

The objective of this study is to evaluate the primary prophylaxis with $\beta$-blocker in cirrhotic children and adolescents with portal hypertension.

\section{METHODS}

This is a cohort study encompassing 26 cirrhotic patients who underwent primary prophylaxis for upper gastrointestinal bleeding at the Hospital das Clínicas of the Federal University of Minas Gerais (HC/UFMG), Brazil, between 2004 and 2014. The endoscopic findings were classified based on the "General Rules for Recording Endoscopic Findings of Esophagogastric Varices (2nd edition)" by Japanese Research Society for Portal Hypertension $^{(20)}$. Patients were evaluated by endoscopy, and those who had varicose veins of medium and large caliber or reddish spots, regardless of the caliber of varices, received primary prophylaxis.

$\beta$-blocker prophylaxis was performed with proprano$1 \mathrm{ol}, 1 \mathrm{mg} / \mathrm{kg} /$ day initially $\mathrm{q} 8 \mathrm{hr}$, tiltrated to reduce the basal heart rate by $25 \%$ and not exceeding $5 \mathrm{mg} / \mathrm{kg} / \mathrm{day}$ or $320 \mathrm{mg} / \mathrm{day}$, and were evaluated every month until this value was reached and every 3 months thereafter. EVL was performed in patients with contraindications to $\beta$-blockers or those who discontinued treatment due to adverse effects or poor compliance. The endoscopic procedure, elastic bandage, was done in accordance to the Protocol of the Service. The elastic bandage was performed using a multi band ligator (Wilson-Cook Medical, USA), under general anesthesia performed by pediatric anesthesiologist. The ligation started near the gastroesophageal junction, heading $5 \mathrm{~cm}$ cephalically. In each session, all the eligible varices found were connected using elastic rings. The procedure was repeated every 3 weeks until eradication of the varices. Follow-up examinations were performed every 3 months during the first 6 months, then after 6 months and, finally, annually, if no varices were found.

Data such as gender, age at first endoscopy and when prophylaxis was started, cause of cirrhosis, laboratory and clinical data, type of prophylaxis (propranolol or endoscopic), follow-up time and date of gastrointestinal bleeding were searched on the patients' medical records.

The patient database was developed and analyzed using the program SPSS 17. Continuous variables with normal distribution were expressed as mean and standard deviation (SD) and continuous variables without normal distribution were expressed as median and 25\%-75\% interquartile range (IQ $25-75 \%$ ).

The study was approved by the Research Ethics Committee of the Federal University of Minas Gerais, number 254/04.

\section{RESULTS}

Of the 26 patients evaluated, $10(38.4 \%)$ were male and had a median of 7.9 years old (25\%-3/ 75\%-13) at the start of primary prophylaxis. They were followed for 2.3 years (25\%-1.3/ 75\%-3.3).

Seventeen started prophylaxis with propranolol with a median of 7.6 years old $(P 25 \%=3.5 / P 75 \%=13.2)$ at the start of therapy and had a median follow-up time of 2.7 years $(P 25 \%=1.2 / P 75 \%=3.5)$, five with autoimmune hepatitis and seven with biliary atresia. Six $(35.3 \%)$ patients of seventeen bleed, with a median time of 1.9 years $(P 25 \%=0.6$ / $P 75 \%=2.9)$ of propranolol use. Three $(17.6 \%)$ of the six patients that bled died during the follow-up period due to acute bleeding when they used propranolol. They died after a median of 2.9 years $(P 25 \%=1.65 / P 75 \%=3.15)$ of propranol use and with a median of 6.9 years old $(P 25 \%=4.2$ / $P 75 \%=7.5)$. Four $(66.6 \%)$ of the six patients that bled had biliary atresia.

In seven $(41.2 \%)$ patients the propranolol prophylaxis were suspended during the study, with a median of 8.6 years old (25\%-6.4 / 75\%-13.1) at the time of suspension, and median of 1.2 years $(P 25 \%=0.85 / P 75 \%=2.2)$ of propranolol use, three by not achieved the $\beta$-blockage and four by side effects, such as drowsiness, bronchospasm and hypotension. Data of patients who underwent beta blocker prophylaxis are shown in Table 1.

Patients who underwent endoscopic prophylaxis with elastic band ligation are shown in Table 2. Thirteen patients were included in this group, nine with initial contraindications to propranolol use and four that were referred from betablocker group by side effects or betablockage failure. They had a median of 9 years old $(P 25 \%=2.4 / P 75 \%=12.3)$ and had a median follow-up time of 2.2 years $(P 25 \%=1.9 /$ $P 75 \%=2.6$ ). In this group, seven had biliary atresia and two autoimmune hepatitis. No bleeding episodes and no deaths in this group were observed.

Table 3 and Figure 1 shows the summary of results.

In summary, 17 patients started primary prophylaxis with beta blocker, nine were male gender. Biliary atresia and autoimmune hepatitis were the most prevalent diagnoses, with seven and three cases respectively. They were followed for median of 2.7 years. Six patients had upper gastrointestinal bleeding after a median time of 1.9 years and three died.

In the endoscopic procedure group, of the 13 patients, 9 were female gender, and biliary atresia was the most prevalent diagnoses in seven cases. The median follow-up time of this group was 2.2 years, and no patient had bleeding.

The Figure 1 summarize the results and the global avaliation of the study. 
TABLE 1. Description of 17 children and adolescents with cirrhosis who underwent propranolol prophylaxis

\begin{tabular}{|c|c|c|c|c|c|c|}
\hline$\#$ & Gender & Diagnosis & $\begin{array}{c}\text { Grade of } \\
\text { Varices at start } \\
\text { of therapy }\end{array}$ & $\begin{array}{l}\text { Age at start } \\
\text { of therapy (yr) }\end{array}$ & Therapy & Follow-up (yr) \\
\hline $1 *$ & $\mathrm{M}$ & BA & Medium & 13.6 & $\begin{array}{l}\text { Suspended after } 2.7 \text { years } \\
\quad \text { (failed } \beta \text {-blockage) }\end{array}$ & 2.7 \\
\hline $2 *$ & $\mathrm{~F}$ & $\mathrm{BA}$ & Medium & 6.9 & $\begin{array}{l}\text { Suspended after } 1.7 \text { years } \\
\text { (unresponsive to a dose of } 4.6 \mathrm{mg} / \mathrm{kg} \text { ) }\end{array}$ & 1.7 \\
\hline 3 & M & Others & Medium & 4.7 & $\beta$-blockage achieved at $3.1 \mathrm{mg} / \mathrm{kg}$ & 6 \\
\hline 4 & $\mathrm{M}$ & BA & Large & 13.8 & $\beta$-blockage achieved at $1.0 \mathrm{mg} / \mathrm{kg}$ & 3.5 \\
\hline $6 *$ & M & PSC & Medium & 7.6 & $\begin{array}{l}\text { Suspended after } 6 \text { months } \\
\text { (drowsiness) }\end{array}$ & 0.5 \\
\hline 7 & $\mathrm{~F}$ & BA & Large & 2.9 & $\begin{array}{l}\text { Suspended after } 2.4 \text { months } \\
\text { (bronchospasm) }\end{array}$ & Bleed after 0.4 \\
\hline 8 & $\mathrm{~F}$ & Others & Medium & 3.5 & $\begin{array}{l}\text { Suspended after } 1.2 \text { years } \\
\text { (hypotension and convulsion) }\end{array}$ & Bleed and died after 3.4 \\
\hline 9 & M & $\mathrm{AH}$ and $\mathrm{AC}$ & Medium & 13.2 & $\beta$-blockage achieved at $1.0 \mathrm{mg} / \mathrm{kg}$ & 4.8 \\
\hline 14 & M & $\mathrm{BA}$ & Large & 1.2 & $\beta$-blockage achieved at $1.0 \mathrm{mg} / \mathrm{kg}$ & Bleed after 1.0 \\
\hline 15 & $\mathrm{~F}$ & $\mathrm{AH}$ & Medium & 10.8 & $\begin{array}{c}\text { Suspended after } 3 \text { years } \\
\text { (drowsiness) }\end{array}$ & 3.7 \\
\hline 16 & $\mathrm{M}$ & BA & Large & 1.1 & $\beta$-blockage achieved at $1.0 \mathrm{mg} / \mathrm{kg}$ & Bleed and died after 0.4 \\
\hline $17 *$ & M & $\mathrm{AH}$ and $\mathrm{AC}$ & Large & 11.2 & $\begin{array}{l}\text { Suspended after } 1.2 \text { years } \\
\text { (failed } \beta \text {-blockage) }\end{array}$ & 1.2 \\
\hline
\end{tabular}

BA: biliary atresia; AH: autoimmune hepatitis; PSC: primary sclerosing cholangitis; ChC: choledocal cyst; CC: cryptogenic cirrhosis; AC: autoimmune cholangitis; GV: gastric varices. M: male; F: female. * Went to EVL after using $\beta$-blocker.

TABLE 2. Description of 13 children and adolescents with cirrhosis who underwent endoscopic prophylaxis

\begin{tabular}{|c|c|c|c|c|c|}
\hline \# & Gender & Diagnosis & $\begin{array}{l}\text { Grade of } \\
\text { Varices } \\
\text { at start of } \\
\text { therapy }\end{array}$ & $\begin{array}{l}\text { Age at } \\
\text { start of } \\
\text { therapy } \\
(y r)\end{array}$ & $\begin{array}{c}\text { Follow-up } \\
(\mathrm{yr})\end{array}$ \\
\hline $1 *$ & M & BA & Medium & 13.8 & 6.7 \\
\hline 18 & $\mathrm{~F}$ & $\mathrm{AH}$ and $\mathrm{AC}$ & $\begin{array}{l}\text { Medium and } \\
\text { GV }\end{array}$ & 4.9 & 10.3 \\
\hline $2 *$ & $\mathrm{~F}$ & BA & Large & 9.1 & 0.2 \\
\hline $6 *$ & M & PSC & Medium & 9.0 & 2.1 \\
\hline 19 & $\mathrm{~F}$ & $\mathrm{CC}$ & Large & 10.3 & 2.5 \\
\hline 20 & $\mathrm{~F}$ & $\mathrm{CC}$ & Large & 16.0 & 2.2 \\
\hline 21 & M & BA & Large and GV & 14.0 & 1.7 \\
\hline 22 & $\mathrm{~F}$ & BA & Large & 1.2 & 2.3 \\
\hline 23 & $\mathrm{~F}$ & $\mathrm{BA}$ & Large & 3.2 & 2.0 \\
\hline 24 & $\mathrm{~F}$ & BA & Large & 2.4 & 0.2 \\
\hline 25 & $\mathrm{~F}$ & $\mathrm{BA}$ & Medium & 2.0 & 3.0 \\
\hline 26 & $\mathrm{~F}$ & $\mathrm{CC}$ & Large & 2.1 & 0.3 \\
\hline $17 *$ & M & $\mathrm{AH}$ and $\mathrm{AC}$ & Large & 12.3 & 2.2 \\
\hline
\end{tabular}

BA: biliary atresia; AH: autoimmune hepatitis; PSC: primary sclerosing cholangitis; CC: cryptogenic cirrhosis; AC: autoimmune cholangitis; GV: gastric varices. M: male; F: female. * Went to EVL after using $\beta$-blocker.
TABLE 3. Summary of primary prophylaxis

\begin{tabular}{|c|c|c|c|c|c|}
\hline Therapy & $\mathbf{N}$ & Gender & Diagnosis & Follow-up (yr) & Bleeding \\
\hline$\beta$-blocker & 17 & $\begin{array}{l}8 \mathrm{~F} \\
9 \mathrm{M}\end{array}$ & $\begin{array}{c}7 \mathrm{BA} \\
3 \mathrm{AH} \text { and AC } \\
3 \text { others } \\
2 \mathrm{AH} \\
1 \mathrm{PSC} \\
1 \mathrm{ChC}\end{array}$ & $\begin{array}{l}2.7 \text { (median) } \\
(\mathrm{p} 25 \% \quad 1.2 / \\
\text { p75\% }=3.5)\end{array}$ & $\begin{array}{l}6, \text { after } \\
\text { median of } \\
1.9 \mathrm{yr} \text {, and } \\
3 \text { deaths }\end{array}$ \\
\hline EVL & 13 & $\begin{array}{l}9 \mathrm{~F} \\
4 \mathrm{M}\end{array}$ & $\begin{array}{c}7 \mathrm{BA} \\
3 \mathrm{CC} \\
1 \mathrm{PSC} \\
2 \mathrm{AH} \text { and } \mathrm{AC}\end{array}$ & $\begin{array}{c}2.2 \text { (median) } \\
(\mathrm{p} 25 \% 1,7 / \\
\mathrm{p} 75 \% 3,5)\end{array}$ & 0 \\
\hline
\end{tabular}

BA: biliary atresia; $\mathrm{AH}$ : autoimmune hepatitis; PSC: primary sclerosing cholangitis; $\mathrm{ChC}$ : choledocal cyst; CC: cryptogenic cirrhosis; AC: autoimmune cholangitis. F: female; M: male.

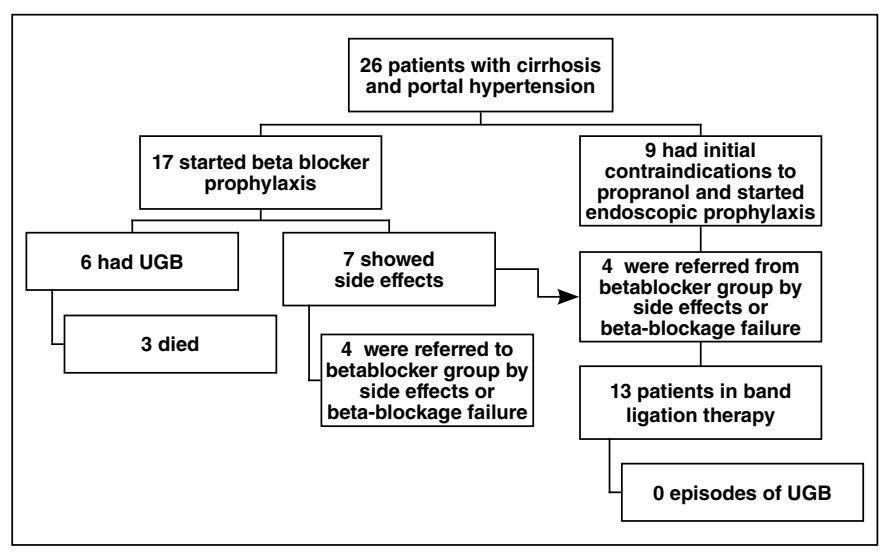

FIGURE 1. Summary and global avaliation

UGB: upper gastrointestinal bleeding. 


\section{DISCUSSION}

Considering the limited experience of primary prophylaxis with beta blocker in children and adolescents with cirrhosis and portal hypertension, and the need for greater knowledge about the indications in pediatric patients, this study had the initial objective to evaluate the use of propranolol in pediatric patients. One of its limitations is the small sample size, as well as other few studies present in the pediatric literature.

The primary objective of pharmacologic therapy for variceal bleeding is to reduce portal pressure and, consequently, intravariceal pressure ${ }^{(16)}$. Nonselective $\beta$-blockers, such as propranolol, can decrease portal flow, intrahepatic vasoconstriction, and the splanchnic blood flow ${ }^{(16)}$. In adults, a dose reducing heart rate by $25 \%$ decreases the bleeding rate in cirrhosis ${ }^{(3)}$. In children, the evaluation of heart rate in rest is problematic and the range of drug dosage to reduce it by $25 \%$ is very wide, making achievement of proper dosage impractical and time consuming ${ }^{(3)}$. Other issues regarding the use of $\beta$-blockers are the prolonged need for therapy, the risk of bleeding after cessation and the frequent side effects and contraindications ${ }^{(13)}$.

In adults, the effectiveness of endoscopic primary prophylaxis and drug primary prophylaxis are similar, with reduced reporting rates of bleeding and mortality ${ }^{(7,14)}$.

The first study of propranolol in children was published in 1985. The authors demonstrated a decrease portal vein pressure after drug administration on 13 children. However, there was no follow-up of patients or the control group, in order to determine the risk of gastrointestinal bleeding. The authors suggest that the drug may be useful in portal hypertension compensated or decompensated and emphasize the good tolerance and low incidence of side effects ${ }^{(12)}$.

Samanta et al. ${ }^{(13)}$ evaluated 41 patients, most of them with small caliber esophagus varices according the criteria of $\mathrm{Conn}^{(2)}$, and had great results, with a low rate of bleeding. The adverse effects have not been addressed, only being cited the absence of hypotension in patients during follow-up. Shashidhar et al. reported the experience with the use of propranolol in 21 children and adolescents with portal hypertension, 19 patients with cirrhosis and two with portal vein obstruction. In this retrospective, non-randomized, uncontrolled study, children aged 9 months to 18 years received propranolol in a dose of 0.6 to $7.0 \mathrm{mg} / \mathrm{kg} / \mathrm{day}$, in two to four times a day. The study was not homogeneous, as evaluated patients undergoing primary and secondary prophylaxis. The measurement of venous portal gradient was not obtained. Despite the limitations, 14 of 21 children showed no episodes of upper gastrointestinal bleeding while receiving medication. Of the seven patients who bled two did not adhere to treatment and two did not show reduction of at least $25 \%$ of heart rate. Excluding these patients, episodes of upper gastrointestinal bleeding occurred in $19 \%$ of cirrhotic patients adequately treated. The beneficial impact of this prophylactic measure was not adequately demonstrated due to the absence of the control group and randomization ${ }^{(17)}$. They reported side effects such as urtical rash, dizziness, bradycardia, hypotension and depression in $33 \%$ of patients, without interruption of treatment in any case.
In the present study, $\beta$-blockage dosage varied from 1 $\mathrm{mg} / \mathrm{kg} /$ day to $3.1 \mathrm{mg} / \mathrm{kg} /$ day and seven patients $(41.2 \%)$ had the propranolol suspended due to the fail of $\beta$-blockage or adverse effects, such as drowsiness, bronchospasm and hypotension. The dosage of propranolol used at the pediatrics studies were $1 \mathrm{mg} / \mathrm{kg} /$ day to $2 \mathrm{mg} / \mathrm{kg} / \mathrm{day}$, orally ${ }^{(13,17)}$. Six $(35.3 \%)$ of the 17 patients who received $\beta$-blocker had bled after a median follow-up time of 1.9 years (0.6-2.9), and $3(17.6 \%)$ died due to bleeding. The high rates of side effects such as those presented in this study and the difficulty in reaching the beta blockade are hindering the use of propranolol in pediatric patients, leading to studies with low numbers of patients. The bleeding rate of $35.3 \%$ observed in this study is similar to that of $31.5 \%$ observed in the study of Shashidhar et al. ${ }^{(17)}$. Samanta et al. ${ }^{(13)}$ reported a lower bleeding rate, that was $4.9 \%$. Only these studies have evaluated the bleeding rate of children receiving primary prophylaxis with $\beta$-blocker.

The Expert Pediatric Opinion on the Report of the Baveno V Consensus Workshop on Methodology of Diagnosis and Therapy in Portal Hypertension states all patients who have medium or large caliber varicose veins, or red spots on varicose veins, regardless of the caliber of esophageal varices must be evaluated to receive primary prophylaxis, preferably by the method of EVL, and that the use of beta blockers as a way to primary prophylaxis should be restricted to research centers ${ }^{(18)}$. There are few studies in the pediatric population, in general case series, with small numbers of patients, similar to our study ${ }^{(1,13,17,15)}$.

EVL can prevent variceal bleeding through rubber band ligation of the variceal vessel, causing a mechanical strangulation ${ }^{(9)}$. EVL is often not a practical option for small children because it is difficult to insert the device-attached endoscopic probe into their small esophageal lumen ${ }^{(10)}$. The usefulness of primary prophylaxis of bleeding by endoscopic obliteration in children is still unproven ${ }^{(3)}$. A randomized controlled trial suggested that sclerotherapy is effective as primary prophylaxis for variceal bleeding in children; however, the study showed an increased incidence of congestive hypertensive gastropathy and gastric bleeding after the procedure $^{(4,8)}$. Sclerotherapy has not been indicated for primary prophylaxis in children, due to its unfavorable adverse effect profile, and it recommends the use of EVL as a way to primary prophylaxis ${ }^{(18,19)}$. In this study, none of the 13 patients who received EVL had bled, showcasing be an effective and safe method for the pediatric age group.

Bleeding occurs in approximately $30 \%$ of patients with varices $^{(16)}$. In this study, despite the onset of primary prophylaxis six $(23.1 \%)$ out of 26 bleed. A bleeding episode from esophageal varices is associated with significant adverse sequelae, such as blood transfusion and intensive care ${ }^{(11)}$. A mortality ratio of $19 \%$ was reported among North American children with liver diseases of various etiologies, within 35 days of variceal bleeding episodes ${ }^{(5)}$. The mortality of cirrhotic children at the time of first bleeding episode is estimated to be $5 \%-15 \%{ }^{(3)}$. Three $(50 \%)$ of the six patients that bleed in this series end up dying. 
In conclusion, all of the six patients that had upper gastroinstestinal bleeding were under propranolol prophylaxis. The high suspension rate $(41.2 \%)$ due to adverse effects or poor compliance in patients using propranolol makes it impractible to be used as primary prophylaxis, despite its potential, but not proved, benefits. The endoscopic primary prophylaxis seemed to be safe and effective, since none of the patients who underwent EVL bled or had significant complications during the follow-up.

It's a small case series, with a few number of patients, and aimed to be a larger study. Given the side effects, low adherence and bleeding rate in the propranolol group, we suspended the routine use of propranolol for primary prophylaxis at our institution and all electable children receive EVL.

However, more studies are needed to show the real efficacy and safety of propranolol and endoscopic prophylaxis for variceal bleeding in cirrhotic children.

\section{Authors' contributions}

Pimenta JR: implementation of research, writing and statistical analysis. Ferreira AR: implementation of research, writing and statistical analysis. Bittencourt PFS: search execution. Resende CB: data collection, writing and analysis statistics. Fagundes EDT: search execution. Silva IML: data collection.

Pimenta JR, Ferreira AR, Bittencourt PFS, Resende CB, Fagundes EDT, Silva IML. Avaliação da profilaxia primária em crianças e adolescentes cirróticos com propranolol e ligadura elástica. Arq Gastroenterol. 2016,53(4):257-61.

RESUMO - Contexto - A eficácia dos beta-bloqueadores e de procedimentos endoscópicos como a ligadura elástica endoscópica para profilaxia primária de ruptura de varizes de esôfago em adultos cirróticos já foram demonstrados por inúmeros ensaios clínicos na população adulta, porém poucos são os estudos envolvendo a faixa etária pediátrica. Objetivo - Avaliar a profilaxia primária com $\beta$-bloqueador em crianças e adolescentes cirróticos com hipertensão porta. Métodos - Estudo de coorte envolvendo 26 pacientes cirróticos. O propranolol foi o $\beta$-bloqueador utilizado para a profilaxia. Quando contraindicado o uso de $\beta$-bloqueador, ou se efeitos colaterais presentes, os pacientes eram encaminhados para profilaxia endoscópica com ligadura elástica. Os pacientes foram avaliados por endoscopia, e naqueles que foram observadas varizes de médio e/ou grosso calibre ou presença de manchas avermelhadas nas varizes, independentemente do calibre das varizes, a profilaxia primária foi indicada. Resultados - Dos 26 pacientes avaliados, $9(34,6 \%)$ tinham contraindicações para o uso de propranolol e foram encaminhados para a profilaxia endoscópica. Seis (35,3\%) dos 17 pacientes que receberam $\beta$-bloqueador (propranolol) apresentaram sangramento após mediana de tempo de acompanhamento de 1,9 anos. A dose de $\beta$-bloqueio variou de $1 \mathrm{mg} / \mathrm{kg} / \mathrm{dia}$ a $3,1 \mathrm{mg} / \mathrm{kg} /$ dia e em sete $(41,2 \%)$ pacientes o propranolol foi suspenso por falha em atingir $\beta$-bloqueio ou presença de efeitos adversos, tais como sonolência, broncoespasmo e hipotensão. No grupo de pacientes que receberam a profilaxia endoscópica (ligadura elástica) não foi observado nenhum episódio de hemorragia digestiva alta durante o período de acompanhamento. Conclusão - Todos os pacientes que apresentaram hemorragia digestiva alta no presente estudo estavam recebendo profilaxia com propranolol. Foi observado, ainda, elevado número de contraindicações e efeitos colaterais, com consequente encaminhamento para profilaxia endoscópica. A profilaxia endoscópica foi eficaz na redução de episódios de hemorragia digestiva alta.

DESCRITORES - Cirrose hepática. Varizes esofágicas e gástricas, terapia. Prevenção de doenças. Propranolol. Endoscopia gastrointestinal, reabilitação. Crianças. Adolescente.

\section{REFERENCES}

1. Celinska-Cedro D, Teisseyre M, Woynarowski M, Socha P, Socha J, Ryzko J. Endoscopic ligation of esophageal varices for prophylaxis of first bleeding in children and adolescents with portal hypertension: preliminary results of a prospective study. J Pediatr Surg. 2003;38:1008-11.

2. Conn HO. Ammonia tolerance in the diagnosis of eosophagealvarices. A comparison of endoscopic, radiologic and biochemical techniques. J Lab Clin Med. 1967;70:442-51.

3. D'Antiga L. Medical management of esophageal varices and portal hypertension in children. Semin Pediatr Surg. 2012;21:211-8.

4. dos Santos JM, Ferreira AR, Fagundes ED, Ferreira AP, Ferreira LS, Magalhães $\mathrm{MC}$, et al., Endoscopic and pharmacological secondary prophylaxis in children and adolescents with esophageal varices. J Pediatr Gastroenterol Nutr. 2013;56:93-8.

5. Eroglu Y, Emerick KM, Whitingon PF, Alonso EM. Octreotide therapy for control of acute gastrointestinal bleeding in children. J Pediatr Gastroenterol Nutr. 2004;38:41-7.

6. Garcia-Tsao G, Sanyal AJ, Grace ND, Carey W, et al., Prevention and management of gastroesophageal varices and variceal hemorrhage in cirrhosis. Hepatology. 2007;46:922-38.

7. Gluud LL, Krag A. Banding ligation versus beta-blockers for primary prevention in oesophageal varices in adults. Cochrane Database Syst Rev. 2012;8:CD004544.

8. Goncalves ME, Cardoso SR, Maksoud JG. Maksoud, Prophylactic sclerotherapy in children with esophageal varices: long-term results of a controlled prospective randomized trial. J Pediatr Surg. 2000;35:401-5

9. Kim SJ, Kim KM. Recent trends in the endoscopic management of variceal bleeding in children. Pediatr Gastroenterol Hepatol Nutr. 2013;16:1-9.

10. Kim SJ, Oh SH, Jo JM, Kim KM. Experiences with endoscopic interventions for variceal bleeding in children with portal hypertension: a single center study. Pediatr Gastroenterol Hepatol Nutr. 2013;16:248-53.
11. Ling SC, Walters T, McKiernan PJ, Schwarz KB, Garcia-Tsao G, Shneider BL, et al. Primary prophylaxis of variceal hemorrhage in children with portal hypertension: a framework for future research. J Pediatr Gastroenterol Nutr. 2011;52:254-61.

12. Ozsoylu S, Koçak N, Yüce A. Propranolol therapy for portal hypertension in children. J Pediatr. 1985;106:317-21.

13. Samanta T, Purkait R, Sarkar M, Misra A, Ganguly S, et al. Effectiveness of beta blockers in primary prophylaxis of variceal bleeding in children with portal hypertension. Trop Gastroenterol. 2011;32:299-303.

14. Sarin SK, Lamba GS, Kumar M, Misra A, Murthy NS, et al., Comparison of endoscopic ligation and propranolol for the primary prevention of variceal bleeding. N Engl J Med. 1999;340:988-93.

15. Sasaki T, Hasegawa T, Nakajima K, Tanano H, Wasa M, Fukui Y, Okada A. Endoscopic variceal ligation in the management of gastroesophageal varices in postoperative biliary atresia. J Pediatr Surg. 1998;33:1628-32.

16. Sharara AI, Rockey DC. Gastroesophageal variceal hemorrhage. N Engl J Med. 2001;345:669-81.

17. Shashidhar H, Langhans N, Grand RJ. Grand, Propranolol in prevention of portal hypertensive hemorrhage in children: a pilot study. J Pediatr Gastroenterol Nutr. 1999;29:12-7.

18. Shneider BL, Bosch J, de Franchis R, Emre SH, Groszmann RJ, Ling SC, et al Portal hypertension in children: expert pediatric opinion on the report of the Baveno v Consensus Workshop on Methodology of Diagnosis and Therapy in Portal Hypertension. Pediatr Transplant. 2012;16:426-37.

19. Shneider BL, de Ville de Goyet J, Leung DH, Srivastava A, Ling SC, Duché M, et al. Primary prophylaxis of variceal bleeding in children and the role of MesoRex Bypass: Summary of the Baveno VI Pediatric Satellite Symposium. Hepatology. 2016;63:1368-80

20. Tajiri T, Yoshida H, Obara K, Onji M, Kage M, Kitano S, et al., General rules for recording endoscopic findings of esophagogastric varices (2nd edition). Dig Endosc. 2010;2:1-9. 